\title{
Immunoglobulins and dietary protein antibodies in childhood coeliac disease ${ }^{1}$
}

\author{
K. G. KENRICK AND J. A. WALKER-SMITH
}

From the Children's Medical Research Foundation, Royal Alexandra Hospital for Children, and the Department of Child Health, University of Sydney, and Royal Alexandra Hospital for Children, Camperdown, New South Wales, Australia

SUMMARY Twenty-four children with coeliac disease were compared with a control group, comprising 17 children with a variety of gastroenterological disorders, with respect to serum immunoglobulins and dietary protein antibodies. Elevated levels of $\operatorname{IgA}$ and abnormally low levels of IgM were demonstrated in one third of the coeliac patients. Antibodies to at least one of eight dietary proteins were found in $50 \%$ of coeliac children. Three children with raised levels of serum IgA and two with deficient IgM were re-examined after varying periods on a gluten-free diet. Antibodies to dietary proteins had waned and immunoglobulin levels returned to normal in all cases. The raised $\operatorname{IgA}$ was considered to have resulted from an extensive immunological response to antigens of dietary origin which had entered through the abnormal gut mucosa. It is suggested that IgM deficiency was due to specific inhibition of IgM synthesis by dietary components which had also entered through the mucosa.

Childhood and adult forms of coeliac disease are associated with gluten intolerance (Dicke, Weijers, and van de Kamer, 1953; Rubin and Dobbins, 1965). The exact mechanism by which gluten exerts its effect on the gut mucosa of the susceptible individual is obscure, but the suggestion that the primary defect in coeliac disease is due to a deficiency of intramucosal peptidases or glutaminase is as yet unproven since enzymatic activity is restored to normal with time when gluten is eliminated from the diet (Douglas and Booth, 1968; Gelfand, Spiro, and Herskovic, 1968). Similarly, the proposal that the primary defect in coeliac disease has an immunological basis remains unproven (Taylor, 1965; Housley, Asquith, and Cooke, 1969). Nevertheless, there have been reports of an increased incidence of disorders of the lymphoreticular system in adult coeliac disease (McCarthy, Fraser, Evans, and Read, 1966; Austad, Cornes, Ojough, McCarthy, and Read, 1967; Harris, Cooke, Thompson, and Waterhouse, 1967; Brunt, Sircus, and Maclean,

Received for publication 29 August 1969.

${ }^{1}$ Requests for reprints should be addressed to K. G. Kenrick, PO Box 34, Camperdown, New South Wales 2050, Australia.
1969) and of dysgammaglobulinaemia both in adults and in children (Immonen, 1967; Hobbs and Hepner, 1968; Blecher, Brezechwa-Ajdukiewicz, and McCarthy, 1969). These defects, however, may be coincidental or secondary to the underlying primary abnormality.

The present study was undertaken to verify the finding of dysgammaglobulinaemia in childhood coeliac disease as reported previously by other workers (Immonen, 1967; Hobbs and Hepner, 1968) and to determine the frequency and distribution of antibodies to a number of common dietary proteins.

\section{Materials and Methods}

PATIENTS

Forty-one children admitted to the Royal Alexandra Hospital for Children were studied. The coeliac group comprised 24 children in all of whom small-bowel biopsy demonstrated a flat mucosa under the dissecting microscope and, on histological section, subtotal villous 
atrophy. There was a clinical response to gluten withdrawal from the diet in all patients. At diagnosis they ranged in age from 5 months to 7 years and 5 months. All 24 were studied before a gluten-free diet was begun and eight were studied at variable intervals after commencement of the diet. In all cases examination of blood films revealed no evidence of hyposplenism (Howell-Jolly bodies and poikilocytes). Hypoproteinaemia was found in three coeliac patients (cases 16, 19, and 20). The levels of serum albumin in these children were $2.5,2 \cdot 7$, and $3.3 \mathrm{~g} / 100 \mathrm{ml}$ respectively. The control group consisted of 17 children admitted to hospital with a variety of gastroenterological disorders (Table III), and they ranged in age from 3 months to 3 years.

\section{BIOPSY TECHNIQUE}

The Watson modification of the paediatric Crosby capsule was used to obtain small-bowel biopsies using the technique as described by Walker-Smith (1967).

\section{BLOOD SAMPLES}

Venous or finger-prick blood samples from both the control and coeliac groups were maintained at $37^{\circ} \mathrm{C}$ for at least an hour, centrifuged, and the sera drawn off and stored at $-20^{\circ} \mathrm{C}$ until tested.

\section{BUFFERED SALINE}

Buffered saline $(0 \cdot 1 \mathrm{M} \mathrm{NaN}, 0 \cdot 15 \mathrm{M} \mathrm{NaCl}$, and $0.02 \mathrm{M}$ phosphate buffer $p \mathrm{H} 7 \cdot 2$ ) was used throughout the test procedures.

\section{IMMUNOGLOBULIN ASSAYS}

Serum levels of the three immunoglobins-IgG, IgA, and IgM-were determined by radial immunodiffusion (Mancini, Carbonara, and Heremans, 1965) using Partigen plates. ${ }^{1}$ Three $\mu 1$ each of standard and diluted serum (1: 40 for IgG and $1: 5$ for both IgA and IgM) were introduced into the wells using a microsyringe fitted with a square-cut needle and repeating adaptor. ${ }^{2}$ Immunodiffusion was allowed to proceed for $\mathbf{4 8}$ hours at $25^{\circ} \mathrm{C}$, following which the plates were washed for 48 hours in several changes of buffered saline to elute unreacted proteins from the gel. The precipitin zones were stained by immersing the plates for one hour in $0.3 \%$ Coomassie brilliant blue ${ }^{3}$ in methanol, acetic acid, and water $(3: 1: 6)$. The plates were then destained in several changes of solvent of the same composition (without dye) for 20 hours. The stained precipitin zones were measured with Vernier callipers across one diameter only with the plates viewed on a white luminous screen.

The normal ranges for each class of immuno-

'Behringwerke AG, Marburg, Western Germany.

'Scientific Glass Engineering Pty. Ltd, Melbourne, Australia.

'R 250-, Mann Research Laboratories Inc, New York, USA. globulin, for age, used in this investigation were those of Allansmith, McClellan, Butterworth, and Maloney (1968). Values lying outside the geometric mean \pm 2 standard deviations were considered abnormal.

DOUBLE IMMUNODIFFUSION TESTS FOR ANTIBODIES TO DIETARY PROTEINS

Sera were tested for the presence of dietary protein antibodies using a micro double immunodiffusion procedure (Ouchterlony, 1962; Hirschfeld, 1963). Five $\mathrm{ml}$ of molten $2 \%$ agar $^{1}$ in buffered saline was delivered onto $75 \times 50 \mathrm{~mm}$ glass slides and allowed to gel. Eight patterns each of nine wells were punched in each gel. A pattern consisted of eight equally spaced holes $1.75 \mathrm{~mm}$ in diameter, the centres of which were on a circle of $1 \mathrm{~cm}$ diameter with a $1.75 \mathrm{~mm}$ diameter hole at the centre.

Five $\mu$ l of the patient's serum was introduced into the peripheral wells and $3 \mu \mathrm{l}$ of antigen solution delivered into the central well of the pattern. The gels were maintained in a humid atmosphere for 48 hours at $25^{\circ} \mathrm{C}$ after which they were washed in several changes of buffered saline for 48 hours. The gels were dried overnight at $37^{\circ} \mathrm{C}$ under a layer of Whatman no. 50 filter paper, then washed for a further 24 hours in water, aftcr which the agar layer was dried under filter paper as before. Precipitin lines were stained by immersing the slides in $0.3 \%$ Coomassie brilliant blue for 30 minutes and destained (as for immunoglobulin assays) for 10 to 20 minutes. The gels were air-dried and examined on a white luminous screen for precipitin lines. Reactions were not graded but recorded as either 'positive' or 'negative'.

\section{DIETARY PROTEIN ANTIGENS}

Each serum was tested against at least three different concentrations of each of the following antigens:

\section{Water-soluble wheat proteins}

$0 \cdot 1 \mathrm{M}$ sodium pyrophosphate buffer $(p \mathrm{H} 7)$ extract of Gabo wheat flour $(1.25 \mathrm{mg} / \mathrm{ml})^{2}$ was prepared according to the method of Lee (1968).

\section{Gliadin}

Gliadin was extracted from Gabo wheat flour with $2 \mathrm{M}$ urea according to Lee (1968). The test solution was prepared in buffered saline containing $2 \mathrm{M}$ urea $(1 \cdot 25 \mathrm{mg} / \mathrm{ml})$.

\section{Cow's milk}

Skim cow's milk from the hospital diet kitchen was used after dilution $(1: 16)$.

\footnotetext{
${ }^{1}$ Special Noble, Difco Laboratories, Detroit, Michigan, USA.

${ }^{2}$ Figures in parentheses after each antigen indicate the concentration or dilution which most commonly gave a positive
} reaction in the double-immunodiffusion procedure. 
Goat's milk

Fresh goat's milk was used after appropriate dilution $(1: 8)$.

\section{Crude ovalbumen}

Albumen was separated from hen eggs and diluted in buffered saline $(1: 256)$.

\section{Sheep and bovine muscle extracts}

Ten $\mathrm{g}$ of muscle was levigated with a pestle and mortar, and $10 \mathrm{ml}$ of buffered saline mixed with this; the suspension was centrifuged at $10,000 \mathrm{~g}$ for 15 minutes. Dilutions were prepared from the supernatant $(1: 32)$.

\begin{tabular}{|c|c|c|c|c|c|c|}
\hline \multirow[t]{2}{*}{ Case No. } & \multirow[t]{2}{*}{ Sex } & \multicolumn{2}{|l|}{ Age } & \multicolumn{3}{|c|}{$\begin{array}{l}\text { Immunoglobulin Levels } \\
(\mathrm{mg} / 100 \mathrm{ml})\end{array}$} \\
\hline & & $Y r$ & Mth & $I g G$ & $\operatorname{Ig} A$ & $I g M$ \\
\hline 1 & $\mathbf{F}$ & & 5 & 650 & $400^{1}$ & 72 \\
\hline 2 & $\mathbf{M}$ & & 6 & 300 & 62 & 26 \\
\hline 3 & $\mathbf{F}$ & & 10 & 710 & $115^{1}$ & 68 \\
\hline 4 & $\mathbf{M}$ & & 11 & 560 & 90 & 80 \\
\hline 5 & $\mathbf{M}$ & 1 & & $280^{2}$ & $120^{1}$ & $27^{2}$ \\
\hline 6 & $\mathbf{F}$ & 1 & & 860 & $125^{1}$ & 88 \\
\hline 7 & $\mathbf{F}$ & 1 & & 640 & $180^{1}$ & 88 \\
\hline 8 & $\mathbf{M}$ & 1 & 3 & 500 & 57 & $34^{2}$ \\
\hline 9 & $\mathbf{F}$ & 1 & 4 & 760 & 100 & 78 \\
\hline 10 & $\mathbf{F}$ & 1 & 6 & 720 & 100 & $37^{2}$ \\
\hline 11 & $\mathbf{F}$ & 1 & 6 & 450 & 50 & 50 \\
\hline 12 & $\mathbf{F}$ & 1 & 8 & 560 & 75 & 47 \\
\hline 13 & $\mathbf{F}$ & 1 & 8 & $1,960^{1}$ & $280^{1}$ & $310^{1}$ \\
\hline 14 & $\mathbf{M}$ & 1 & 9 & 840 & 36 & $36^{2}$ \\
\hline 15 & $\mathbf{M}$ & 2 & 5 & 430 & 80 & 52 \\
\hline 16 & $\mathbf{M}$ & 2 & 11 & 640 & 175 & $30^{2}$ \\
\hline 17 & $\mathbf{F}$ & 3 & & 1,440 & $<5^{2}$ & 138 \\
\hline 18 & $\mathbf{M}$ & 3 & 6 & $250^{2}$ & 43 & $17^{2}$ \\
\hline 19 & $\mathbf{F}$ & 4 & & 830 & $290^{1}$ & $28^{2}$ \\
\hline 20 & $\mathbf{M}$ & 4 & & 800 & 165 & $28^{2}$ \\
\hline 21 & $\mathbf{M}$ & 6 & 1 & 720 & 125 & 145 \\
\hline 22 & $\mathbf{M}$ & 6 & 6 & 660 & 136 & 82 \\
\hline 23 & $\mathbf{M}$ & 7 & & 1,330 & $325^{1}$ & 64 \\
\hline 24 & $\mathbf{M}$ & 7 & 5 & 720 & 200 & 110 \\
\hline
\end{tabular}

Table I Immunoglobulin levels in 24 children with untreated coeliac disease

${ }^{1}$ Above normal range (Allansmith et al, 1968).

${ }^{2}$ Below normal range (Allansmith et al, 1968).

\begin{tabular}{|c|c|c|c|c|c|c|c|c|}
\hline \multirow[t]{3}{*}{ Case No. } & \multirow[t]{3}{*}{ Sex } & \multicolumn{6}{|c|}{ Immunoglobulin Levels $(\mathrm{mg} / 100 \mathrm{ml})$} & \multirow{3}{*}{$\begin{array}{l}\text { Time on } \\
\text {-Diet } \\
\text { (mth) }\end{array}$} \\
\hline & & \multicolumn{2}{|l|}{$I g G$} & \multicolumn{2}{|l|}{$\operatorname{IgA}$} & \multicolumn{2}{|l|}{$I g M$} & \\
\hline & & $\begin{array}{l}\text { Before } \\
\text { Diet }\end{array}$ & $\begin{array}{l}\text { After } \\
\text { Diet }\end{array}$ & $\begin{array}{l}\text { Before } \\
\text { Diet }\end{array}$ & $\begin{array}{l}\text { After } \\
\text { Diet }\end{array}$ & $\begin{array}{l}\text { Before } \\
\text { Diet }\end{array}$ & $\begin{array}{l}\text { After } \\
\text { Diet }\end{array}$ & \\
\hline $\begin{array}{r}1 \\
5 \\
6 \\
7 \\
8 \\
13 \\
15 \\
21\end{array}$ & $\begin{array}{l}\mathbf{F} \\
\mathbf{M} \\
\mathbf{F} \\
\mathbf{F} \\
\mathbf{M} \\
\mathbf{F} \\
\mathbf{M} \\
\mathbf{M}\end{array}$ & $\begin{array}{c}650 \\
280^{2} \\
860 \\
640 \\
500 \\
1,960^{1} \\
430 \\
720\end{array}$ & $\begin{array}{r}800 \\
470 \\
960 \\
800 \\
470 \\
1,450 \\
560 \\
1,040\end{array}$ & $\begin{array}{c}400^{1} \\
120^{1} \\
125 \\
180^{1} \\
57 \\
280^{1} \\
80 \\
125\end{array}$ & $\begin{array}{r}32 \\
44 \\
56^{3} \\
205^{1} \\
30 \\
75 \\
82 \\
130\end{array}$ & $\begin{array}{c}72 \\
27^{2} \\
88 \\
88 \\
34^{2} \\
310^{1} \\
52 \\
145\end{array}$ & \begin{tabular}{r|r|r}
118 \\
64 \\
123 \\
95 \\
72 \\
120 \\
73 \\
125
\end{tabular} & $\begin{array}{r}10 \\
18 \\
3 \\
1 \\
16 \\
4 \\
3 \\
3\end{array}$ \\
\hline
\end{tabular}

Table II Effect of a gluten-free diet on immunoglobulin levels in eight children with coeliac disease

${ }^{1}$ Greater than geometric mean plus $2 \mathrm{SD}$.

${ }^{2}$ Less than geometric mean minus 2 SD.

'After a further five months on a gluten-free diet this value rose to $130 \mathrm{mg} / 100 \mathrm{ml}$ which is also normal for the age.

\section{Bovine serum}

Bovine serum ${ }^{1}$ was diluted before use with buffered saline $(1: 256)$.

\section{Results}

\section{IMMUNOGLOBULIN LEVELS}

Serum immunoglobulin levels for each of the untreated coeliac patients are set out in Table I. It can be seen that one coeliac patient had an elevated serum level of IgG and that two had abnormally low levels of IgG for their age. Thirty-three per cent of the cases (eight of 24) had elevated levels of IgA, while one child had no detectable IgA. This patient fitted the classification of dysgammaglobulinaemia type IVB (Hobbs, 1968). One coeliac patient had a raised level of IgM and eight (33\%) had levels of IgM below the normal range. There was no apparent correlation between the high levels of IgA and the low IgM values.

Immunoglobulin levels were estimated in eight coeliac patients before and after the introduction of a gluten-free diet. The results are shown in Table II. Case 5 had an abnormally low IgG and case 13 raised levels of $\mathrm{IgG}$ and IgM at diagnosis. These returned to normal after 18 and four months respectively on a gluten-free diet. Cases 1 , 5 , and 13 all had elevated levels of $\operatorname{IgA}$, which returned to normal after 10,18 , and four months respectively on a gluten-free diet. Case 7 still had a raised level of IgA one month after being put onto a gluten-free diet. Two patients (cases 5 and 8) had abnormally low levels of IgM at

\begin{tabular}{|c|c|c|c|c|c|c|c|}
\hline \multirow[t]{2}{*}{$\begin{array}{l}\text { Case } \\
\text { No. }\end{array}$} & \multirow[t]{2}{*}{ Diagnosis } & \multirow[t]{2}{*}{ Sex } & \multicolumn{2}{|c|}{ Age } & \multicolumn{3}{|c|}{$\begin{array}{l}\text { Immunoglobulin } \\
\text { Levels }(\mathrm{mg} / 100 \mathrm{ml})\end{array}$} \\
\hline & & & $\boldsymbol{Y r}$ & Mth & $I g G$ & $\operatorname{Ig} A$ & $\operatorname{Ig} M$ \\
\hline \multirow{5}{*}{$\begin{array}{l}25 \\
26 \\
27 \\
28 \\
29\end{array}$} & Salmonella enteritis & $\mathbf{F}$ & & 3 & 340 & 10 & 65 \\
\hline & Salmonella enteritis & $\mathbf{M}$ & & 4 & $1,100^{1}$ & 15 & $168^{1}$ \\
\hline & Ileal stricture & $\mathbf{M}$ & & 5 & 380 & 57 & 70 \\
\hline & Salmonella enteritis & $\mathbf{M}$ & & 6 & 520 & 70 & 128 \\
\hline & $\begin{array}{l}\text { Post-gastroenteritis } \\
\text { malabsorption }\end{array}$ & $\mathbf{M}$ & & 7 & 460 & 32 & 60 \\
\hline \multirow{3}{*}{$\begin{array}{l}30 \\
31 \\
32\end{array}$} & Acute enteritis & $\mathbf{M}$ & & 7 & 540 & 43 & 38 \\
\hline & Malabsorption & $\mathbf{M}$ & 1 & 3 & 980 & 20 & 150 \\
\hline & $\begin{array}{l}\text { Post-gastroenteritis } \\
\text { malabsorption }\end{array}$ & $\mathbf{M}$ & 1 & 5 & 920 & 46 & 64 \\
\hline \multirow[t]{2}{*}{33} & Post-gastroenteritis & & & & & & \\
\hline & malabsorption & $\mathbf{F}$ & 1 & 7 & 720 & 140 & 140 \\
\hline \multirow{8}{*}{$\begin{array}{l}34 \\
35 \\
36 \\
37 \\
38 \\
39 \\
40 \\
41\end{array}$} & Shigella enteritis & $\mathbf{M}$ & 1 & 7 & 760 & 65 & 110 \\
\hline & Chronic diarrhoea & $\mathbf{M}$ & 1 & 8 & 1,120 & 125 & 55 \\
\hline & Chronic diarrhoea & $\mathbf{M}$ & 1 & 9 & 840 & 50 & 46 \\
\hline & Lactose intolerance & $\mathbf{M}$ & 1 & 9 & 610 & 94 & 77 \\
\hline & Acute enteritis & $\mathbf{M}$ & 2 & & 540 & $15^{2}$ & $175^{1}$ \\
\hline & Lactose intolerance & $\mathbf{F}$ & 2 & 4 & 840 & 72 & 80 \\
\hline & Salmonella enteritis & $\mathbf{M}$ & 2 & 8 & 460 & 110 & 47 \\
\hline & malabsorption & $\mathbf{M}$ & 3 & & 920 & 59 & 61 \\
\hline
\end{tabular}

Table III Immunoglobulin in levels in 17 children with various gastroenterological disorders

'Above normal range (Allansmith et al, 1968).
'Below normal range (Allansmith et al, 1968),

'Commonwealth Serum Laboratories, Melbourne, Australia. 


\begin{tabular}{|c|c|c|c|c|c|c|c|c|}
\hline $\begin{array}{l}\text { Case } \\
\text { No. }\end{array}$ & $\begin{array}{l}\text { Phosphate } \\
\text { Buffered } \\
\text { Extract of } \\
\text { Wheat Flour }\end{array}$ & $\begin{array}{l}\text { Gliadin } \\
r\end{array}$ & $\begin{array}{l}\text { Cow's } \\
\text { Milk }\end{array}$ & $\begin{array}{l}\text { Goat's } \\
\text { Milk }\end{array}$ & Ovalbumin & $\begin{array}{l}\text { Extract } \\
\text { of Sheep } \\
\text { Muscle }\end{array}$ & $\begin{array}{l}\text { Extract } \\
\text { of Bovine } \\
\text { Muscle }\end{array}$ & $\begin{array}{l}\text { Bovine } \\
\text { Serum }\end{array}$ \\
\hline 1 & POS & POS & POS & POJ & $\mathrm{NT}^{2}$ & NT & NT & NT \\
\hline 2 & POS & - & - & - & - & - & - & - \\
\hline 3 & POS & POS & PJS & POS & $N T^{2}$ & $\mathrm{~N} \Gamma$ & $\mathrm{Nr}$ & NT \\
\hline 4 & - & - & POS & - & - & - & - & POS \\
\hline 5 & - & - & POS & - & - & - & POS & POS \\
\hline 6 & POS & POS & POS & POS & NT & $\mathrm{N} \Gamma$ & NT & NT \\
\hline 7 & POS & POS & POS & POS & POS & - & POS & - \\
\hline 9 & - & - & POS & - & POS & - & - & POS \\
\hline 10 & - & - & POS & POS & POS & POS & POS & POS \\
\hline 11 & - & - & - & - & - & - & - & - \\
\hline 12 & - & - & - & - & - & - & - & - \\
\hline 13 & - & - & - & - & - & - & - & - \\
\hline 14 & POS & POS & POS & - & POS & - & - & - \\
\hline 15 & - & - & - & - & NT & NT & NT & $\Lambda T$ \\
\hline 16 & - & - & - & - & - & - & - & - \\
\hline 17 & - & - & - & - & - & - & - & - \\
\hline 18 & - & - & POS & POS & - & POS & POS & POS \\
\hline 21 & - & - & - & - & - & - & - & - \\
\hline 22 & - & - & POS & - & - & - & - & POS \\
\hline 23 & - & - & - & - & NT & NT & NT & NT \\
\hline 24 & POS & POS & - & - & - & - & - & - \\
\hline
\end{tabular}

Table IV Antibodies to dietary proteins in 21 children with untreated coeliac disease

${ }^{1} \mathrm{POS}=$ Precipitins demonstrated by double immunodiffusion. ${ }^{2} \mathrm{NT}=$ Not tested.

\begin{tabular}{lrl}
\hline Antigen & $x^{2}$ & $P$ \\
\hline Phosphate buffer extract of wheat & $4 \cdot 9$ & $<0.05$ \\
Gliadin & $3 \cdot 8$ & Not significant \\
Cow's milk & $10 \cdot 1$ & $<0.01$ \\
Goat's milk & $3 \cdot 8$ & Not significant \\
Ovalbumen & $2 \cdot 8$ & Not significant \\
Extract of sheep muscle & $0 \cdot 6$ & Not significant \\
Extract of bovine muscle & $2 \cdot 8$ & Not significant \\
Bovine serum & $5 \cdot 5$ & $<0.05$ \\
\hline
\end{tabular}

Table V Comparison of the frequency of dietary protein antibodies in coeliac and control groups

'Yates' correction for continuity was applied.

\begin{tabular}{|c|c|c|c|c|c|c|c|c|c|}
\hline \multirow[t]{2}{*}{$\begin{array}{l}\text { Case } \\
\text { No. }\end{array}$} & \multicolumn{2}{|c|}{$\begin{array}{l}\text { Phosphate Buffer } \\
\text { Extract of } \\
\text { Wheat Flour }\end{array}$} & \multicolumn{2}{|l|}{ Gliadin } & \multicolumn{2}{|c|}{ Cow's Milk } & \multicolumn{2}{|c|}{ Goat's Milk } & \multirow[t]{2}{*}{$\begin{array}{l}\text { Time on } \\
\text { Diet } \\
\text { (mth) }\end{array}$} \\
\hline & $\begin{array}{l}\text { Before } \\
\text { Diet }\end{array}$ & $\begin{array}{c}\text { After } \\
\text { Diet }\end{array}$ & $\begin{array}{l}\text { Before } \\
\text { Diet }\end{array}$ & $\begin{array}{c}\text { After } \\
\text { Diet }\end{array}$ & $\begin{array}{l}\text { Before } \\
\text { Diet }\end{array}$ & $\begin{array}{l}\text { After } \\
\text { Diet }\end{array}$ & $\begin{array}{l}\text { Before } \\
\text { Diet }\end{array}$ & $\begin{array}{l}\text { Afier } \\
\text { Diet }\end{array}$ & \\
\hline$T$ & POS $^{1}$ & $-^{2}$ & POS & $-^{2}$ & POS & POS $^{2}$ & POS & POS $^{2}$ & 10 \\
\hline 5 & - & - & - & - & POS & - & - & - & 18 \\
\hline 6 & POS & $\operatorname{POS}^{3}$ & POS & - & POS & POS $^{3}$ & POS & $-^{3}$ & 9 \\
\hline 7 & POS & - & POS & - & POS & POS & POS & POS & 1 \\
\hline 13 & - & - & - & - & - & - & - & - & 4 \\
\hline 15 & - & - & - & - & 一 & - & - & - & 3 \\
\hline 21 & - & - & - & - & - & - & - & - & 3 \\
\hline
\end{tabular}

Table VI Effect of a gluten-free diet on dietary protein antibodies in six children with coeliac disease

'Precipitins demonstrated by double immunodiffusion analysis. ${ }^{2}$ Established after five months on a gluten-free diet.

'Established after three months on a gluten-free diet. diagnosis. When tested again after 18 and 16 months respectively on a gluten-free diet these children had normal IgM levels for their ages.

Immunoglobulin levels for the children in the control group are shown in Table III. Only two patients (cases 26 and 38) had immunoglobulin levels lying outside the defined normal range for their ages.

The frequency of increased levels of $\operatorname{IgA}$ (eight of 24) and abnormally low levels of IgM (eight of 24) in coeliac patients were both found to be statistically significant $\left(\chi^{2}=5 \cdot 1, \mathrm{P}<0.05\right)$ when compared with the occurrence in the control group (none out of 17).

\section{ANTIBODIES TO DIETARY PROTEINS}

Table IV summarizes the distribution of antibodies to various dietary proteins for the coeliac group. It can be seen that $33 \%$ (seven of 21 ) had precipitins to pyrophosphate extract of wheat flour. Twenty-nine per cent (six out of 21) had antibodies to both gliadin and goat's milk and $52 \%$ of patients (11 out of 21 ) had antibodies to cow's milk. Twenty-five per cent of cases (four of 16) had antibodies to both ovalbumen and bovine muscle extract, while $12 \%$ (two of 16 ) and $37 \%$ (six of 16 ) had precipitins to sheep muscle extract and bovine serum respectively.

The serum from every member of the control group was tested against the same panel of eight dietary protein antigens, but on no occasion were precipitins demonstrated.

When coeliac and control group data were compared for each of the antigens (Table V), significant differences between the groups were found for antibodies to pyrophosphate extract $(\mathrm{P}<0.005)$, to cow's milk $(\mathrm{P}<0.01)$, and to bovine serum $(\mathrm{P}<0.05)$.

Table VI shows the dietary protein antibodies in seven coeliac patients before and after the introduction of a gluten-free diet. Cases 13, 15, and 21 did not show any antibodies at the time of diagnosis nor subsequently. Patients 1,6 , and 7 , who all had antibodies to gliadin at diagnosis, did not have demonstrable gliadin precipitins after 10 and nine months and one month respectively on a gluten-free diet. Antibodies to cow's milk were demonstrated in the serum of case 5 at diagnosis, but were no longer demonstrable after 18 months on a gluten-free diet. Similarly it can be seen that antibodies to water-soluble wheat proteins dropped to below detectable levels after 10 months and one month in cases 1 and 7 respectively, yet cow's milk and goat's milk antibodies remained at detectable levels. Case 6 behaved differently after nine months on a gluten-free diet. Antibodies to pyrophosphate wheat extract and cow's milk remained at detectable levels yet gliadin and goat's milk antibodies were no longer demonstrable. Despite the persistence of cow's milk antibodies in cases 1,6 , and 7 , these patients were

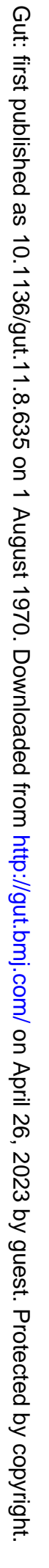


all accepting normal quantities of milk and showed no clinical evidence of milk intolerance.

\section{Discussion}

The finding of elevated levels of serum $\operatorname{IgA}$ in eight out of 24 coeliac patients, coupled with the finding of antibodies to dietary proteins, is indicative of a considerable immunological response to exogenous antigenic stimulation. The abnormal gut mucosa in these patients is the probable site of entry for these antigens and it is likely that the local immunological mechanisms of the gut are mainly involved. Therefore, at diagnosis it is probable that these patients were producing greatly increased quantities of coproantibodies with specificities for various dietary components. Crabbé, Carbonara, and Heremans (1965) have shown that IgA is the predominant immunoglobulin of the gut secretions, and it is likely that normally a proportion of $\operatorname{IgA}$ antibodies produced locally in the gut 'spill over' into the lacteals before the attachment of the 'secretory-piece' (Tomasi, Tan, Solomon, and Prendergast, 1965) and thus contribute to the normal serum IgA level. An important additional contribution to this level could be made by cells producing IgA antibody, which cells constantly migrate from the local 'secretory compartment' of the gut, via the lymphatics, to systemic sites. The elevated levels of serum $\operatorname{IgA}$ observed in childhood coeliac disease may simply reflect an amplification of these normal processes following a considerable increase in antigenic 'background'. The concept that restoration of the integrity of the gut mucosa following the elimination of gluten from the diet minimizes the entry of antigenic material is supported by the demonstration in four children of waning antibodies to dietary proteins and in three children in whom raised IgA levels returned to normal after a gluten-free diet. A similar fall in IgA after taking a glutenfree diet has been recorded by Immonen (1967) in a group of coeliac children in Finland.

It is of interest that the elevation of IgA was found predominantly in children under 2 years of age. These results are similar to those reported by Immonen (1967) and are in accord with the infrequent finding of raised levels of IgA in adult coeliac disease (Hobbs and Hepner, 1968).

Twenty-seven per cent of patients in the coeliac group had abnormally low levels of IgM at diagnosis, a finding which is similar to those of Hobbs and Hepner (1968) and Blecher et al (1969). The low levels of IgM did not correlate with elevated $\operatorname{IgA}$, and apart from the possibility of a protein-losing enteropathy in three children with hypoproteinaemia, there was no correlation with any other clinical findings.

Two cases with IgM deficiency were re- examined after a gluten-free diet had been taken and IgM levels had risen to normal in both. A similar rise in IgM was reported by Hobbs and Hepner (1968) in 16 out of 18 adult coeliac patients. These workers also observed a fall in level when gluten was reintroduced in a group of eight patients in all of whom IgM levels had been restored to normal after a gluten-free diet. This deficiency of $\operatorname{IgM}$, which is apparently acquired, cannot be explained in terms of increased IgM catabolism (Brown, Cooper, and Hepner, 1969). In the absence of any satisfactory explanation, Hobbs and Hepner (1968) and Brown et al (1969) have suggested that this acquired abnormality may be a further manifestation of the lymphoreticular dysfunction observed in adult coeliac disease. Lymphoreticular dysfunction is rare in childhood coeliac disease (McCarthy et al, 1966). For this reason and the apparent lack of any evidence of hyposplenism in the present group of coeliac children, it was necessary to seek another explanation for the observed, apparently acquired, defect in IgM synthesis.

One possible explanation is that gluten or other antigenic dietary components, independently or in combination, exert a direct suppressive effect on IgM production. Possible sites of action could be the antigen-processing cell or the antibody-producing cell. It has been estimated that more than half the lymphoid cells of the body are localized along the gastrointestinal tract (Yoffey and Courtice, 1956; Smith, 1969). Represented among these are cells synthesizing IgM (Rubin, Fauci, Sleisenger, Jeffries, and Margolis, 1965). It is possible that these cells are more susceptible than the cells producing IgG or IgA to the action of specific inhibitors or critical concentrations of antigens which have entered through the abnormal gut mucosa. Any interference with the function of these cells would result in depression of local IgM production in the gut. Without this normal contribution the serum levels would become abnormally low. Most of the remaining circulating IgM in untreated patients would then be produced by cells at sites other than the gut. The work of Villa, Mocarelli, Natale, and Clerici (1968) has shown that in experimental animals under special conditions IgM synthesis can be specifically depressed. They found that in mice, which received repeated injections of antigens above a certain critical concentration, there was a marked inhibition of the IgM phase of the antibody response.

It is suggested, therefore, that the acquired IgM deficiency seen in untreated coeliac disease is a secondary defect and that lymphoreticular dysfunction need not be implicated as a complicating factor. However, this does not exclude the possibility that continued depressed IgM synthesis in the untreated coeliac gut could ultimately lead to the development of lymphoreticular dysfunction. 


\section{K. G. Kenrick and J. A. Walker-Smith}

We wish to thank Dr C. W. Wrigley, csiro Wheat Research Unit, North Ryde, Miss Cheryl Yum, Department of Dietetics, Royal Alexandra Hospital for Children, for antigen preparations, and Miss Mary O'Halloran, Institute of Pathology, Royal Alexandra Hospital for Children, for the collection of blood samples.

\section{References}

Allansmith, M., McClellan, B. H., Butterworth, M., and Maloney, J. R. (1968). The development of immunoglobulin levels in man. J. Pediat., 72, 276-290.

Austad, W. I., Cornes, J. S., Gough, K. R., McCarthy, C. F., and Read, A. E. (1967). Steatorrhea and malignant lymphoma. The relationship of malignant tumors of lymphoid tissue and celiac disease. Amer. J. dig. Dis., 12, 475-490.

Blecher, T. E., Brzechwa-Adjukiewicz, A., McCarthy, C. F., and Read, A. E. (1969). Serum immunoglobulins and lymphocyte transformation studies in coeliac disease. Gut, 10, 57-62.

Brown, D.L., Cooper, A. G., and Hepner, G. W. (1969). IgM metabolism in coeliac disease. Lancet, 1, 858-861.

Brunt, P. W., Sircus, W., and Maclean, N. (1969). Neoplasia and the coeliac syndrome in adults. Lancet, 1, 180-184.

Crabbé, P. A., Carbonara, A. O., and Heremans, J. F. (1965). The normal human intestinal mucosa as a major source of plasma cells cortaining $\gamma$-immunoglobulin. Lab. Invest., 14, 235-248.

Dicke, W. K., Weijers, H. A., and van de Kamer, J. H. (1953). Coeliac disease. II. The presence in wheat of a factor having a deleterious effect in cases of coeliac disease. Acta paediat. (Uppsala), 42, 34-42.

Douglas, A. P., and Booth, C. C. (1968). Jejunal mucosal digestion of gluten peptides in adult coeliac disease. Lancet, 2, $491-492$.

Gelfand, M. D., Spiro, H. M., and Herskovic, T. (1968). Small intestine glutaminase deficiency in celiac disease. Amer. J. dig. Dis., 13, 638-642.

Harris, O. D., Cooke, W. T., Thompson, H., and Waterhouse, J. A. H. (1967). Malignancy in adult coeliac disease and idiopathic steatorrhoea. Amer. J. Med., 42, 899-912.

Hobbs, J. R., and Hepner, G. W. (1968). Deficiency of Mglobulin in coeliac disease. Lancet, 1, 217-220.

Housley, J., Asquith, P., and Cooke, W. T. (1969). Immune response to gluten in adult coeliac disease Brit. med. J., 2, 159-161.

Immonen, P. (1967). Levels of the serum immunoglobulins $\gamma \mathrm{A}$ $\gamma \mathbf{G}$ and $\gamma \mathrm{M}$ in the malabsorption syndrome in children. Ann. Paediat. Fenn., 13, 115-153.

Lee, J. W. (1968). J. Sci. Fd Agric., 19, 153.

Mancini, G., Carbonara, A. O., and Heremans, J. F. (1965). Immunochemical quantitation of antigens by single radial immunodiffusion. Immunochemistry, 2, 235-254.

McCarthy, C. F., Fraser, I. D., Evans, K. T., and Read, A. E. (1966). Lymphoreticular dysfunction in idiopathic steatorrhoea. Gut, 7, 140-148.

Ouchterlony, O. (1962). Diffusion-in-gel methods for immunological analysis. II. Progr. Allergy, 6, 30-154.

Rubin, C. E., and Dobbins, W. O., III. (1965). Peroral biopsy of the small intestine. A review of its diagnostic usefulness. Gastroenterology, 49, 676-697.

Rubin, W., Fauci, A. S., Sleisenger, M. H., and Jeffries, G. H. (1965). Immunofluorescent studies in adult celiac disease. J. clin. Invest., 44, 475-485.

Smith, R. T. (1969). Gamma-A immunoglobulins and the concept of local immunity. Pediatrics, 43, 317-321.

Taylor, K. B. (1965). Role of immune responses in the gastrointestinal tract. Fed. Proc., 24, 23-28.

Tomasi, T. B., Jr., Tan, E. M., Solomon, A., and Prendergast, R. A. (1965). Characteristics of an immune system common to certain external secretions. J. exp. Med., 121, 101-124.

Villa, M. L., Mocarelli, P., Natale, N., and Clerici, E. (1968). Inhibition of the macroglobulinaemic phase of the antibody responses. Nature (Lond.), 220, 1051-1052.

Walker-Smith, J. (1967). Dissecting microscope appearance of small bowel mucosa in children. Arch. Dis. Childh., 42, 626-630.

Yoffey, J. M., and Courtice, F. C. (1956). Lymphatics, Lymph and Lymphoid Tissue. Arnold, London. 